\title{
Accuracy Development Through Computerized Storytelling: A Preliminary Study on Student-Generated CALL
}

\author{
Justin Nicholes \\ Fort Hays State University, U.S.A. \\ Sias International University, China
}

\begin{abstract}
This preliminary study explores how student-generated computer-assisted language learning (CALL) materials can help students acquire verb tenses. The participants were 23 Chinese university sophomores in an integrated-skills English Composition 101 course. The students were earning U.S. Bachelor of Business Administration degrees in China through a cross-border program. After taking pre-tests, students viewed a video that contextualized tenses. Students then wrote narratives using target tenses and incorporated images using presentation software. After showing presentations to classmates, students took post-tests. Open-ended questionnaires measured interest in CALL and grammar learning. Target verb forms were the simple present, present progressive, present perfect, simple past, past progressive, and past perfect tenses.
\end{abstract}

This preliminary study responds to Chinese Department of Higher Education directives. In China, teacher- and test-centered language classes have dominated, sometimes producing learners with weak speaking and listening skills. The Chinese government, however, has called for change. Lu, Li, and Du (2009) have discussed the Department of Higher Education's call for more student-centered, communicative language teaching (CLT) approaches in English language classes, especially through the incorporation of computer-assisted language learning (CALL). Shen and Suwanthep (2011) have given direction to China-based English as a foreign language (EFL) teachers, showing that "e-learning constructive role plays" represent one way CALL can improve Chinese students' speaking abilities (p. 23). Li (2007), however, listed challenges to change in Chinese educational settings, such as hardware and software availability, a shortage of technical and theoretical knowledge regarding CALL, stubborn traditional teaching models, and questions about how to manage students engaged with CALL materials. This study seeks to contribute to the body of research guiding English teachers in China toward sound CLT and CALL use, with implications for teachers across Asia. 


\section{CALL, Task-Based Learning, and Sociocultural Theory}

According to Gruba (2004), "CALL is now widely regarded as the central acronym to refer to studies concerned with second language and computer technology" (p. 623). This definition of CALL, according to Shield (2009), provides a relatively broad "interpretation of the ways in which computers may be used by language learners (and teachers)" (p. 13). Chapelle (2002) described CALL materials used in the classroom as having the following qualities: "(1) language learning potential, (2) learner fit, (3) meaning focus, (4) authenticity, (5) positive impact, and (6) practicality" (p. 499). In addition to meaning-focused tasks, Godwin-Jones (2009) emphasized a need for pre- and post-CALL form-focused activities and suggested that putting students into active roles "makes it more likely that form features will be noticed and retained" (p. 8). Fang (2010), Tschichold (1999), and Milton (1997) also acknowledged the importance of learner autonomy and motivation in CALL environments, while Gobel (2008) recommended teachers help students "understand how each individual task type relates to learning and student progress" to keep students motivated and on task (p. 15).

Sociocultural theory offers helpful ideas for meaningful, motivating CALL design and use. According to Vygotsky (2002), all learning begins in social environments; later CALL researchers have drawn from Vygotsky and proposed CALL materials simulate or describe realworld situations so that language can become internalized into privatized thought, which enables "autistic and logical thinking" (Vygotsky, 2002, p. 35). Papert (1980) advanced the idea of using simulated microworlds to present tasks that simulate a controlled reality. Since then, others have argued for the benefits of providing students with simulated realities (Hmelo \& Day, 1999), arguing that language encountered in simulations can be later used for higher mental processes.

Building from Vygotsky, Lantolf (2002) asserted that ESL students' engagement with tasks and technology leads to cognitive development in terms explained by sociocultural theory, since both task-based second language (L2) learning and first language (L1) acquisition hold a theoretical parallel. In this view, computer-assisted tasks should help L2 learners become meaningful members of a target culture. Foley (1991) supported the importance of tasks, arguing that "task-based learning figures as an 'enabling process' that allows learners to recognize their agency as linguistically constituted beings [and] meaningful member[s] of the target linguistic community" (p. 73). In addition, Donato (2000) expressed that learners should not be "separated from the cultural institutions and historical conditions in which they learn" (pp. 46-47), offering further theoretical justification for task-based learning. Artifact mediation also involves technology (Lantolf, 2002), and Gánem-Gutiérrez (2003) provided a "blueprint as to how [researchers] can implement and empirically investigate computer-based tasks in the second language classroom from a sociocultural perspective" (p. 94), saying computer-based tasks should involve "collaboration, negotiation of meaning, and problem-solving endeavors" (p. 97).

Since Slamecka and Graf (1978) found self-generated texts were more memorable than already-generated texts, researchers and designers of materials have looked for ways to recreate the generation effect. By creating simulations that ask learners to generate language for unique, memorable situations, teachers may help students recognize language as it exists in the target sociocultural context, which in turn, according to Vygotsky (1978), facilitates the internalization of privatized speech. Willis (1996) composed a helpful framework for taskbased teaching to guide teachers: (a) a pre-task step, in which students review the task's topic, view models of language used to complete the task, and engage in other activities that help them learn language needed to finish the task; (b) a task-cycle step, in which students work through the task while being monitored by the instructor, after which they report on the steps 
taken to succeed; and (c) a language-focus step, in which students analyze language the task elicited, allowing them to continue practicing forms used in real-world social contexts.

Such a framework also ensures that needs of language learners are met, such as the input, feedback, and output needs mentioned by Mayo and Pica (2000), who said that communicative tasks alone cannot meet the needs of EFL learners. Accordingly, tasks should do more than allowing learners to generate output in real-time, in simulated real-world situations, in response to authentic native speaker (NS) input. Tasks should also provide learners opportunities to internalize aspects of language used in the simulated reality through self-scaffolding (by which learners help themselves develop through cognitive or social language learning strategies as well as through the use of their L1) and, additionally, peerscaffolding, which remains an important aspect of tasks informed by sociocultural theory. To return to Gánem-Gutiérrez's (2003) work, peer-scaffolding happens when tasks encourage collaboration, negotiation of meaning, and problem-solving (p. 97). Wood, Bruner, and Ross (1976), Antón (1999), and Donato (1994) further detailed ways EFL learners can scaffold each other, just as an instructor might scaffold a beginner.

Integrating CALL and multimedia to simulate worlds may present challenges. For instance, Caspi, Gorsky, and Privman (2005) reported participant frustration with video, caused by "context retrieval, involving rewinding and replaying" as well as "cognitive overload" when learners had to listen, watch, and also take notes (p. 44). To avoid such overload, Sabet and Shalmani (2010) recommended "presenting texts as narrations so that both visual and auditory channels are engaged" (p. 31). Ultimately, if its integration prevents frustration, multimedia can scaffold language learners. Multimedia researchers have supported the use of still images, text, and sound in language acquisition (Erben, Ban, \& Castañeda, 2009; Hubbard, 2009; Jones, 2004), and more specific research on video has further justified its use (Çakir, 2006; Hemei, 1997; Lin, 2010; Rhodes \& Puhfahl, 2003). Akbulut (2007), as well as Kim and Gilman (2008), explored how multimedia leads to vocabulary acquisition at a much more rapid rate than other more analytic approaches to vocabulary teaching. Jones (2004) found that words, when contextualized with pictures, were more likely to be remembered. Hu and Deng (2007) attributed greater vocabulary retention to students' paying more attention to instruction that coupled sound and image. Finally, Smidt and Hegelheimer (2004) noted the potential for incidental vocabulary acquisition through CALL involvement.

\section{Research Method}

\section{Research Design and Primary Objective}

Utilizing a one-group pre-test and post-test design, this preliminary study explored how student-generated CALL in an integrated-skills writing class could help Chinese learners acquire verb tenses. Surveys elicited feedback about motivation toward working with computers, and open-ended questions further sought feedback on student motivation and perceptions toward CALL. Helping students do well in content courses, such as marketing, figured as a long-term objective by recycling marketing vocabulary and key concepts for language learning.

\section{Participants}

Twenty-three sophomore-level students working toward a U.S. degree of Bachelor of Business Administration at a Chinese university associated with a U.S. higher education institution agreed to participate in the study. The participants were Chinese nationals in their early twenties. All students had taken freshman-level Oral English courses taught by teachers who 
are native speakers (NS) of English. All learners were taking a sophomore-level Oral English class, an English Composition 101 class (in which this study was conducted), and a Marketing class-all of which were taught entirely in English by NSs. Outside of these classes, students used the Mandarin dialect in educational contexts, as well as provincial dialects.

\section{Instruments}

Students completed 30 sentences with missing verbs on the pre- and post-tests (see Appendix A). Each of the six target verb tenses was represented by five sentences. Each item in the test was worth one point; the maximum score was 30.

A video podcast entitled "Office Talk" (EF podEnglish, n.d.) was shown. A structure of "watch," "learn," and "try" organized the video lesson, with study points of past continuous questions and answers. Though the video did not present authentic NS input that learners might actually encounter in the real world, this three-part structure resembled the framework for task-based teaching that Willis (1996) developed; it also resembled Afsar and Rasheed's (2010) proposed pedagogical framework for grammar teaching. The video alternated scripted office conversations with cloze exercises, in which viewers mentally filled in blanks to complete sentences with missing verbs.

Students generated CALL materials using presentation software. Since students in this major were taking a marketing class, they were asked to narrate an experience with their favorite brand. The task was meant to recycle key marketing concepts and vocabulary. Student narratives involved two parts: in the first part, students told the story as if describing it to a friend on the phone in real time; in the second part, students recounted the event as if it had occurred in the past.

A motivation assessment survey (see Appendix B) measured student-reported motivation to study English after class, asking students to circle a choice from the following list: never, only when I have to, sometimes, most of the time, and every day. The open-ended questionnaire elicited students' thoughts on using presentation software to learn grammar and to teach grammar to classmates.

\section{Procedures}

On Day 1, (a) learners finished a verb tense accuracy pre-test; (b) the researcher explained the objectives of the following activities, and learners viewed the video; (c) learners were given verb tense explanation sheets, on which tenses were diagrammed and explained for reference. Learners were randomly placed in groups of three to four members. In groups, learners planned and drafted narratives as if describing them to a friend in real time on the phone and, secondly, as if recounting the event so that tenses concerning the past time would most accurately convey meaning. The ultimate CALL products were supposed to introduce tenses to fellow students in a way similar to how the video podcast presented and contextualized tenses.

On Day 2, (d) learners met in a computer lab on campus. There, they retrieved Internet images to complement narratives and complete early drafts of presentations. Groups finished presentations at home for the next class.

On Day 3, (e) groups showed presentations (see Appendix C for an example) to learners in the audience, who were supposed to complete checklists to see whether presenters had incorporated all target verb tenses, and ( $\mathrm{f}$ learners took post-tests.

On Day 4, (g) learners completed the motivation-assessment instrument. 


\section{Results and Discussion}

Paired t-tests were performed on the mean scores of pre- and post-tests. In addition, a second t-test examined groups placed into levels of Excellent (with scores ranging from 30-27 out of a possible 30), Good (26-24), Average (23-21), Low (20-18), and Weak (<17). Finally, surveys and open-ended questionnaires measured motivation.

\section{Learner Acquisition of Verb Tenses Through Student-Generated CALL}

While the mean did improve among students by two points (18.78 to 20.78), the paired t-tests on the mean scores of pre- and post-tests (0.111) indicate this overall improvement lacked significance (Table 1).

Table 1

Mean Score Comparisons Between Pre-Test and Post-Test

\begin{tabular}{|c|c|c|c|c|}
\hline $\begin{array}{c}\text { Student } \\
\boldsymbol{N}\end{array}$ & Assessment & Mean & SD & $\begin{array}{c}\text { Sig. } \\
\text { (2-tailed) }\end{array}$ \\
\hline 23 & Pre-test & $\begin{array}{l}18.78 \\
20.78\end{array}$ & $\begin{array}{l}9.33 \\
8.44\end{array}$ & - \\
23 & Post-test & +2.00 & 5.77 & 0.111 \\
& & & & \\
\hline
\end{tabular}

The findings underscore weaknesses of the preliminary study as a final analysis; it also highlights the inability to definitively determine the effectiveness of student-generated CALL used here. Standard deviation also reflected a feature of the student sample: learners of earlybeginner English skills were mixed with students of early-intermediate levels.

Table 2

Mean Score Comparisons Between Pre-Test and Post-Test Among Student Groups

\begin{tabular}{|c|c|c|c|c|c|}
\hline $\begin{array}{l}\text { Student } \\
\text { Groups }\end{array}$ & $N$ & Assessment & Mean & $S D$ & $\begin{array}{c}\text { Sig. } \\
\text { (2-tailed) }\end{array}$ \\
\hline $\begin{array}{c}\text { Excellent } \\
(30-27)\end{array}$ & 5 & $\begin{array}{l}\text { Pre-test } \\
\text { Post-test }\end{array}$ & $\begin{array}{r}28.2 \\
25.6 \\
-2.6\end{array}$ & $\begin{array}{l}0.45 \\
4.28 \\
4.16\end{array}$ & $\begin{array}{c}- \\
- \\
0.234\end{array}$ \\
\hline $\begin{array}{l}\text { Good } \\
(26-24)\end{array}$ & 4 & $\begin{array}{l}\text { Pre-test } \\
\text { Post-test }\end{array}$ & $\begin{array}{l}25.00 \\
27.25 \\
+2.25\end{array}$ & $\begin{array}{l}0.00 \\
2.22 \\
2.22\end{array}$ & $\begin{array}{c}- \\
- \\
0.135\end{array}$ \\
\hline $\begin{array}{c}\text { Average } \\
(23-21)\end{array}$ & 6 & $\begin{array}{l}\text { Pre-test } \\
\text { Post-test }\end{array}$ & $\begin{array}{l}22.17 \\
26.17 \\
+4.00\end{array}$ & $\begin{array}{l}0.75 \\
2.86 \\
3.41\end{array}$ & $\begin{array}{c}- \\
- \\
0.035\end{array}$ \\
\hline $\begin{array}{c}\text { Low } \\
(20-18)\end{array}$ & 0 & $\begin{array}{l}\text { Pre-test } \\
\text { Post-test }\end{array}$ & $\begin{array}{l}-- \\
-- \\
--\end{array}$ & $\begin{array}{l}-- \\
-- \\
--\end{array}$ & $\begin{array}{l}-- \\
-- \\
--\end{array}$ \\
\hline $\begin{array}{l}\text { Weak } \\
(<17)\end{array}$ & 8 & $\begin{array}{l}\text { Pre-test } \\
\text { Post-test }\end{array}$ & $\begin{array}{r}7.25 \\
10.50 \\
+3.25\end{array}$ & $\begin{array}{l}5.09 \\
4.38 \\
8.01\end{array}$ & $\begin{array}{c}- \\
- \\
0.289\end{array}$ \\
\hline
\end{tabular}


Another t-test (Table 2) looked more closely at pre-test-determined student groups. Although all groups but one (Excellent) showed increased mean scores, the t-test indicated that only the Average group showed significant improvement (0.035).

Though the mean score improved (+3.25), the Weak group's improvement was least significant of all. The weakest students seemed to have very little understanding of what the target verb tenses communicate. Working through the study's process did not allow significant change to occur within that group, although some members were able to improve their performance modestly by, it seems, merely noticing context cues (such as adjectivals that signaled which tenses most accurately communicated the appropriate meaning). Although between the Good and Average groups, only the Average group showed statistically significant improvement (0.035 to the Good group's 0.135), these two groups were among the most significantly changed groups from pre- to post-test. As opposed to the Weak group, whose members showed a lack of understanding of all tenses except for the immediate simple present, the Good and Average group members seemed able to turn attention toward lower-frequency tenses (such as the past perfect progressive) since they had already internalized the formmeaning connection of more accessible tenses (e.g., those with present aspects: simple present, present perfect, and present progressive).

Notably, the Excellent group from pre-test results performed worse on the post-test (though significance of that change is also lacking). Though the standard deviation for Excellent students' post-tests (4.28) was higher than in pre-tests (0.45), it is still worth exploring reasons why Excellent students made greater accuracy errors after working through the study. Afsar and Rasheed (2010) have written on the negative effects of teaching situations that make grammar rules explicit without giving enough time for learners to internalize forms through skill integration, specifically through speaking, listening, writing, and reading. "Excellent" students, who had perhaps drawn on procedural knowledge in the pre-test, may have questioned previously formed hypotheses (declarative knowledge) about when and how to use the target verb forms, overthought the post-test prompts, and hypercorrected in response to heightened attention to forms. Ultimately, this finding seems to be an additional justification for combining form-focused and meaning-focused activities in task-based CLT lessons, since making rules explicit (and not following through with meaning-focused activities over a longer period of time) sometimes results in students' forming inaccurate hypotheses of how to use explicitly presented grammatical forms.

\section{CALL and Motivation to Learn Grammar}

Genç and Aydin (2011) noted that "age, gender, grades, compulsory and optional status, types of high school, parents' educational background, the period of the participant's languagelearning process, and the experience toward computer use have effects on the learners' motivational levels" (p. 185). In this preliminary study, learners who scored within the Excellent to Average levels on the pre-test reported higher motivation levels to study English outside of class. This supports the findings of Masgoret and Gardner (2003), who identified motivation as the primary indicator of achievement in CALL classrooms. In open-ended questionnaires, learners from the Excellent to Average levels also reported unanimous interest in using CALL. Many reasons may account for this. For instance, Hong and Samimy (2010) found that "students with higher computer literacy skills were more likely to have positive attitudes toward incorporated CALL modes than did those with lower computer literacy skills" (p. 340). Others have noted the importance of learner confidence in task performance (Coryell \& Chlup, 2007; Hubbard, 2004; Ushida, 2005), with Ayres (2002) finding that face validity results from the value learners append to using computers for language acquisition. Excellent to Average learners may have more experience using computers, may have more confidence in 
their ability to use English through past experiences of success, and also may be more likely to view a teacher's in-class activities as having internal and external validity. Ultimately, all Excellent to Average learners in the study expressed opinions that CALL could help them acquire tenses.

Table 3

Analysis of After-Class Motivation to Learn English by Student Group

\begin{tabular}{|c|c|c|c|}
\hline Group & $N$ & Mean & $S D$ \\
\hline Excellent & $3^{*}$ & 3.33 & 0.58 \\
\hline Good & 4 & 3.25 & 0.50 \\
\hline Average & 6 & 3.33 & 0.82 \\
\hline Low & 0 & -- & -- \\
\hline Weak & 8 & 2.50 & 0.76 \\
\hline
\end{tabular}

Note. 5 = every day; $4=$ most of the time; $3=$ sometimes; $2=$ only when I have to; $1=$ never *Two of five participants from the pre-test Excellent level were absent on the day of questionnaire administration.

Learners who scored within the Weak level, however, showed lower motivation and also were more likely to believe CALL, at least as used in this study, lacked external and internal validity. Student 8, for instance, who scored within the Weak level, reported, "I think if the [presentation software] is useful to writting class or to our future, we should learn it, but, if it not maybe, we will lose time on making [the presentation]." In addition, when asked whether using presentation software was a good way to learn grammar, Student 6, who also scored within the Weak level, wrote, "I do not think so. We always want to use some pictures or somethings to help us show the story means, but not use some verb tense exchange or words to show our thinks."

Among participants in this study, most had never used presentation software before, and all had no choice about whether to study English. These factors may have influenced measurements of motivation, as well as perceptions of the benefits of using CALL to learn grammar. Ultimately, teachers cannot downplay student perceptions. As Cooper and McIntyre (1994) have noted, "pupils exhibit a clearer and more detailed understanding than their teachers of how particular strategies interact with their learning processes" (p. 94). This preliminary study's limitations may have been more apparent to struggling learners, and this apparent lack of face validity may have stunted motivation and performance.

\section{Directions for Future Research}

The most obvious limitation of this study concerns time constraints. The researcher had educational and departmental objectives to meet with these participants and failed to adequately pace procedure steps. Another limitation concerned the small participant sample. Future research can prevent such limitations by the allocation of more time in a pre-task stage. More video and CALL materials can model student-generated products. In addition, students need more practice in creating CALL materials so that the technology becomes easier to use and products better scaffold peers. Finally, delayed post-tests could further measure the effectiveness of student-generated CALL and the acquisition of tenses. 


\section{Implications for Teachers}

Teachers looking to apply these findings might follow this sequence as adapted from Willis' (1996) framework for task-based instruction:

1. Pre-task step (Noticing): One to two hours might be spent on gleaning meaning from texts that exhibit target verb tenses, either contextualized in real-world English or given in a student's presentation from an earlier lesson. As in Afsar and Rasheed's (2010) pedagogical model for grammar teaching, this beginning stage could be highly communicative and meaning focused, allowing students to consider the language in a top-down process.

2. Pre-task step (Planning): One to two hours might be spent on students planning their presentations. Students can sketch "frames" on paper and write out the language needed to explain the situation to fellow students. Students will implicitly notice and implicitly reconstruct target verb forms.

3. Task-cycle step (Creating): Three hours may be needed for students to put together presentations; ideally, this can happen at a university computer lab, where the teacher can monitor and assist. Collaboration and explicit manipulation of target forms should happen here (Afsar \& Rasheed, 2010).

4. Task-cycle step (Communicating): While students are presenting their narratives that contextualize target forms, the audience should listen actively, perhaps to complete information-gap tasks. After each presentation, audience members might paraphrase narratives and also comment on funny situations or memorable parts of the speakers' experiences. In this way, the audience will need to reconstruct target verb forms for clear communication.

5. Language-focus step (Reinforcing): Students should work on form-focused activities that elicit declarative knowledge about when target forms usually appear in real-world language.

With institutional imperatives to prepare Chinese students in particular, as well as Asian learners in general, for real-world communication in English, it behooves ESL teachers in China to seek out ways to incorporate CLT to help prepare learners who desire further education in ESL contexts where educators and administrators untrained in TESL may decry both real and perceived language deficiencies (Swan, 2003; Zamel, 2000) and to ready learners for local contexts that may require real-world interaction with native and non-native speakers of English. With further research, student-generated CALL in which learners tell stories may prove to provide another interesting, motivating way to boost students' accuracy through implicit and explicit grammar activities. Presented as part of an integrated-skills, task-based approach, student-generated CALL may assist in preparing Asian learners for authentic realworld and academic ESL contexts where speakers may expect high levels of grammatical accuracy.

\section{Author Note}

Justin Nicholes, English Department / Virtual College, Fort Hays State University, Kansas, USA and Sias International University, Henan Province, China

Correspondence concerning this article should be addressed to Justin Nicholes. USA address: English Department / Virtual College, Fort Hays State University, 600 Park Street, Hays, Kansas, USA 67601-4099. China address: Sias International University, 168 Renmin Lu, Xinzheng, Henan Province, China 451150. E-mail: jrnicholes@fshu.edu 


\section{References}

Afsar, A., \& Rasheed, F. (2010). From form to function: An integrated-skills model for teaching grammar. Kashmir Journal of Language Research, 13(1). Retrieved from http://www.gale.cengage.com

Akbulut, Y. (2007). Effects of multimedia annotations on incidental vocabulary learning and reading comprehension of advanced learners of English as a foreign language. Instructional Science, 35(6), 499-517. http://dx.doi.org/10.1007/s11251-007-9016-7

Antón, M. (1999). The discourse of a learner-centered classroom: Sociocultural perspectives on teacher-learner interaction in the second-language classroom. The Modern Language Journal, 83(3), 303-318. http://dx.doi.org/10.1111/0026-7902.00024

Ayres, R. (2002). Learner attitudes towards the use of CALL. Computer Assisted Language Learning, 15(3), 241-249. http://dx.doi.org/10.1076/call.15.3.241.8189

Çakir, I. (2006). The use of video as an audio-visual material in the foreign language teaching classroom. The Turkish Online Journal of Educational Technology, 5(4), 67-72. Retrieved from www.tojet.net

Caspi, A., Gorsky, P., \& Privman, M. (2005). Viewing comprehension: Students' learning preferences and strategies when studying from video. Instructional Science, 33(1), 31 47. http://dx.doi.org/10.1007/s11251-004-2576-x

Chapelle, C. A. (2002). Computer-assisted language learning. In R. B. Kaplan (Ed.), The Oxford handbook of applied linguistics (pp. 498-508). Oxford: Oxford University Press.

Cooper, P., \& Mclntyre, D. (1994). Teachers' and pupils' perceptions of effective classroom learning: Conflicts and commonalities (pp. 66-89). In M. Hughes (Ed.), Perceptions of teaching and learning. Bristol, England: Multilingual Matters.

Coryell, J. E., \& Chlup, D. T. (2007). Implementing e-learning components with adult English language learners: Vital factors and lessons learned. Computer Assisted Language Learning, 20(3), 263-278. http://dx.doi.org/10.1080/09588220701489333

Donato, R. (1994). Collective scaffolding in second language learning. In J. P. Lantolf \& G. Appel (Eds.), Vygotskian approaches to second language research (pp. 33-56). Westport, CT: Ablex.

Donato, R. (2000). Sociocultural contributions to understanding the foreign and second language classroom. In J. P. Lantolf (Ed.), Sociocultural theory and second language learning (pp. 27-50). Oxford: Oxford University Press.

EF podEnglish. (n.d.). Learn English 13 - Office talk [Video podcast]. Retrieved from http://www.efjapan.co.jp/podenglish/

Erben, T., Ban, R., \& Castañeda, M. (2009). Teaching English language learners through technology. New York, NY: Routledge.

Fang, Y. (2010). Perceptions of the computer-assisted writing program among EFL college learners. Educational Technology \& Society, 13(3), 246-256. Available at http://www.ifets.info/journals/13_3/22.pdf

Foley, J. (1991). A psycholinguistic framework for task-based approaches to language teaching. Applied Linguistics, 12(1), 62-75. http://dx.doi.org/10.1093/applin/12.1.62

Gánem-Gutiérrez, G. A. (2003). Beyond interaction: The study of collaborative activity in computer-mediated tasks. ReCALL, 15(1), 94-112. http://dx.doi.org/10.1017/S0958344003000818

Genç, G., \& Aydin, S. (2011). Students' motivation toward computer-based language learning. International Journal of Educational Reform, 20(2), 171-189.

Gobel, P. (2008). Student off-task behavior and motivation in the CALL classroom. International Journal of Pedagogies and Learning, 4(4), pp. 4-18. http://dx.doi.org/10.5172/ijpl.4.4.4 
Godwin-Jones, R. (2009). Emerging technologies: Focusing on form - Tools and strategies. Language Learning \& Technology, 13(1), 5-12. Available at http://lt.msu.edu/vol13num1/emerging.pdf

Gruba, P. (2004). Computer-assisted language learning (CALL). In A. Davies \& C. Elder (Eds.), The handbook of applied linguistics (pp. 623-648). Oxford, England: Blackwell.

Hemei, J. (1997). Teaching with video in an English class. English Teaching Forum, 35(2), 4547.

Hmelo, C., \& Day, R. (1999). Contextualized questioning to scaffold learning from simulations. Computers \& Education, 32(2), 151-164. http://dx.doi.org/10.1016/S03601315(98)00062-1

Hong, K. H., \& Samimy, K. K. (2010). The influence of L2 teachers' use of CALL modes on language learners' reactions to blended learning. CALICO Journal, 27(2), pp. 328-348.

Hu, H.-P., \& Deng, L.-J. (2007). Vocabulary acquisition in multimedia environment. US-China Foreign Language, 5(8), 55-59.

Hubbard, P. (2004). Learner training for effective use of CALL. In S. Fotos \& C. M. Browne (Eds.), New perspectives on CALL for second language classrooms (pp. 46-68). Mahwah: NJ: Lawrence Erlbaum.

Hubbard, P. (2009). A general introduction to computer-assisted language learning. In P. Hubbard (Ed.), Computer-assisted language learning: Critical concepts in linguistics (Vol. 1, pp. 1-20). New York, NY: Routledge.

Jones, L. (2004). Testing L2 vocabulary recognition and recall using pictorial and written test items. Language Learning and Technology, 8(3), 122-143. Available from Ilt.msu.edu/vol8num3/pdf/jones.pdf

Kim, D., \& Gilman, D. A. (2008). Effects of text, audio, and graphic aids in multimedia instruction for vocabulary learning. Educational Technology \& Society, 11(3), 114-126. Available at http://www.ifets.info/journals/11_3/9.pdf

Lantolf, J. P. (2002). Sociocultural theory and second language acquisition. In R. B. Kaplan (Ed.), The Oxford handbook of applied linguistics. Oxford: Oxford University Press.

$\mathrm{Li}, \mathrm{J}$. (2007). An attempted evaluation of computer-assisted language learning in China. Canadian Social Science, 3(3), 109-113. Available at http://cscanada.net/index.php/css/article/view/j.css.1923669720070303.017/425

Lin, L.-F. (2010). English learners' incidental vocabulary acquisition in the video-based CALL program. Asian EFL Journal, Special Issue, 12(4), 51-66. Retrieved from http://www.asian-efl-journal.com/PDF/December-2010.pdf

Lu, Z., Li, P., \& Du, P. (2009). Interactive patterns in an English audio-video speaking class in CALL environments. International Journal of Pedagogies, 5(2), pp. 49-66. http://dx.doi.org/10.5172/ijpl.5.2.49

Masgoret, A. M., \& Gardner, R. C. (2003). Attitudes, motivation, and second language learning: A meta-analysis of studies conducted by Gardner and associates. Language Learning, 53(1), 167-210. http://dx.doi.org/10.1111/1467-9922.00227

Mayo, M. d. P. G., \& Pica, T. (2000). Interaction among proficient learners: Are input, feedback, and output needs addressed in a foreign language context? Studia Linguistica, 54(2), 272-279. http://dx.doi.org/10.1111/1467-9582.00066

Milton, J. (1997). Providing computerized self-access opportunities for the development of writing skills. In P. Benson \& P. Voller (Eds.), Autonomy and independence in language learning (pp. 237-263). London, England: Longman.

Papert, S. (1980). Mindstorms: Children, computers, and powerful ideas. New York: Basic Books.

Rhodes, N., \& Puhfahl, I. (2003, December). Teaching foreign languages to children through video. ERIC Digest. Washington, DC: ERIC Clearinghouse on Languages and Linguistics. 
Sabet, M. K., \& Shalmani, H. B. (2010). Visual and spoken texts in MCALL courseware: The effects of text modalities on the vocabulary retention of EFL learners. English Language Teaching, 3(2), 30-36. Available at http://www.ccsenet.org/journal/index.php/elt/article/view/6236/5009

Shen, L., \& Suwanthep, J. (2011). E-learning constructive role plays for EFL learners in China's tertiary education. Asian EFL Journal, Professional Teaching Articles, CEBU Conference Issue (4), 54. 4-29. Available at http://www.asian-efl-journal.com/PTA/August-2011.pdf

Shield, L. (2009). CALL: Using what we know to avoid reinventing the wheel. Indian Journal of Applied Linguistics, 35(1), 11-24.

Slamecka, N. J., \& Graf, P. (1978). The generation effect: Delineation of a phenomenon. Journal of Experimental Psychology: Human Learning and Memory, 4(6), 592-604. http://dx.doi.org/10.1037/0278-7393.4.6.592

Smidt, E., \& Hegelheimer, V. (2004). Effects of online academic lectures on ESL listening comprehension, incidental vocabulary acquisition, and strategy use. Computer Assisted Language Learning, 17(5), 517-556. http://dx.doi.org/10.1080/0958822042000319692

Swan, M. (2003). Seven bad reasons for teaching grammar - and two good ones. In J. C. Richards \& W. A. Renandya (Eds.), Methodology in language teaching (pp. 148-152). Cambridge: Cambridge University Press.

Tschichold, C. (1999). Grammar checking for CALL: Strategies for improving foreign language grammar checkers. In K. Cameron (Ed.), Computer-assisted language learning (CALL): Media, design \& applications (pp. 203-221). Lisse, The Netherlands: Swets \& Zeitlinger.

Ushida, E. (2005). The role of students' attitudes and motivation in second language learning in online language courses. CALICO Journal, 23, 49-78. Available at http://calico.org/html/article_131.pdf

Vygotsky, L. S. (1978). Mind in society: The development of higher psychological processes. Cambridge, MA: Harvard University Press.

Vygotsky, L. S. (2002). Thought and language. Cambridge, MA: MIT Press.

Willis, J. (1996). A framework for task-based learning. Essex, England: Longman.

Wood, D., Bruner, J. S., \& Ross, G. (1976). The role of tutoring in problem solving. Journal of Child Psychology \& Psychiatry, 17, 89-100. http://dx.doi.org/10.1111/j.14697610.1976.tb00381.x

Zamel, V. (2000). Strangers in academia: The experiences of faculty and ESL students across the curriculum. In E. P. J. Corbett, N. Myers, \& G. Tate (Eds.), The writing teacher's sourcebook (4th ed.) (pp. 100-112). New York, NY: Oxford University Press. 


\section{Appendix A \\ Pre- and Post-Test}

Name:

*This is not a test. This is not for a grade.

COMPLETE these sentences with a verb form.

(Run) I always

(Give) My teacher

(Eat) Every night, I

(Make) My mother

(Study)

(Sleep) My friend

(Bring) The waiter

(Take) I

(Cut) The man

(Wait Right now, I

(Eat)

(Travel) She

(Pass) She

(Finish) He

(Date) $\mathrm{He}$

(Win) In 2008, China

(Be) In 2008, there

(See)

(Call)

(Come)

My friend

(Play) When I opened the door, my friends many gold medals in the Beijing Olympics. a big earthquake.

(Study) Students in the library when the lights turned off.

(Sing) The children when I opened the door.

(Sleep) My friend

(Shine) The sun when I called her on the phone.

(Eat) I wasn't hungry. I when I woke up.

(Finish) By the time I got home, my roommate already when my friend brought me food.

(Go) I wanted to see my friend, but when I arrived, she her homework already.

(See) I wanted to watch a movie with my friend, but he already.

(Leave) I could not go home. When I got to the train station, the train already. already. the movie 


\section{Appendix B \\ Motivation Assessment and Open-ended Questionnaire}

This is not a test. Just answer these questions about using PPTs to learn grammar.

(1) Do you enjoy practicing English after class? Circle one:
a. Never
b. Only when I have to
c. Sometimes
d. Most of the time
e. Every day

(2) What do you think about writing stories to learn grammar?

(3) What do you think about using PPT to write stories?

(4) Do you think using PPT to write stories is a good way to learn grammar? Explain.

(5) Do you think students can use PPT to help other students learn grammar? 


\section{Appendix C \\ Student Example of a Presentation}

\section{The Story of I and BOSIDENG}
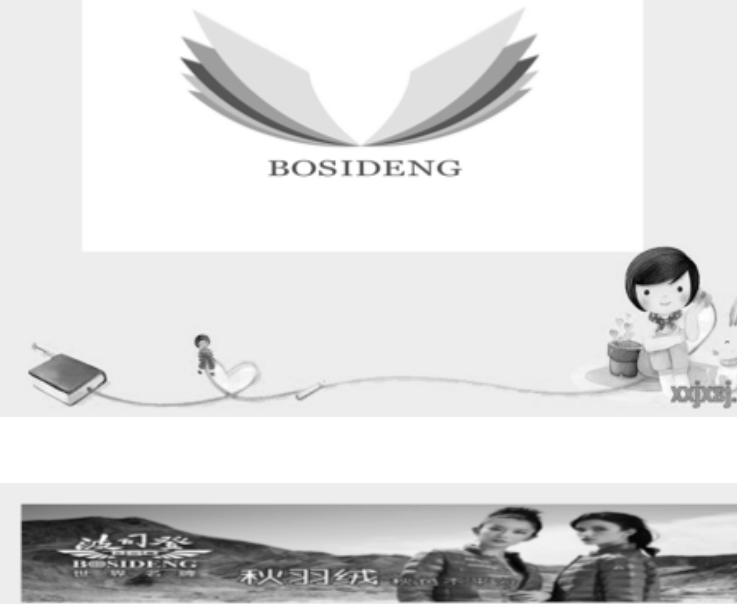

And I even think I have never seen the beautiful down jacket before. So I find a suitable size immediately. When I wear it, my friend and I both think it is designed for me. I decide to buy it without hesitation. After I go back to school, I find that the brand mark is SNOW FLYING! Not the BOSIDENG. I realize that maybe I was cheated by the shop. So I go to the store again and ask the clerk loudly. The store is full of the nervous atmosphere. And I wait for the clerk to give me a reason (pe explanation.

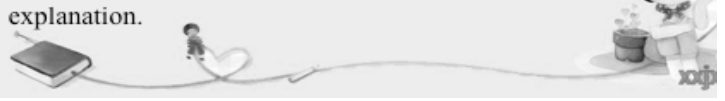

\section{- Second story}

When winter is coming, it gets colder and colder. I decided to buy my own down jacket. So, today, I went to the BSD store which is located in Xinzheng to buy a desirable Clothes. When I was coming in the store, I noticed a very fashionable and beautiful down jacket.

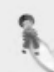

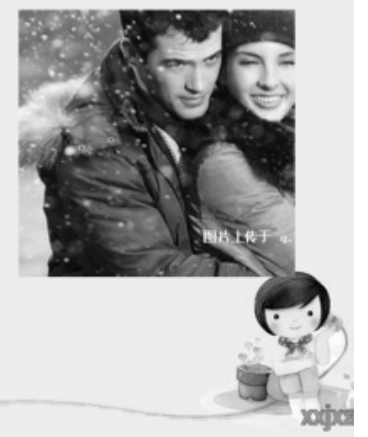

\section{The Story of I and BOSIDENG}

- First Story

When winter is coming, it gets colder and colder. I decide to buy my own down jacket. So, today, I go to the BSD store which is located in Xinzheng to buy a desirable Clothes. When I am coming in the store, I notice a very fashionable and beautiful down

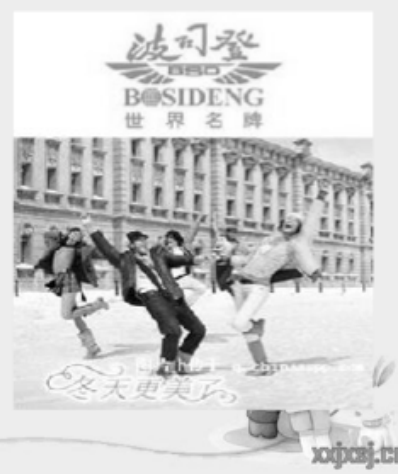
jacket.

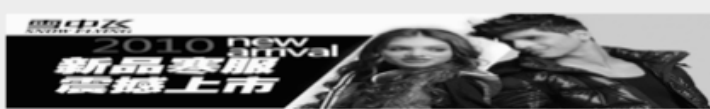

Surprisingly, the clerk explain that the SNOW FLYING is belong to the BOSIDENG.

It means I also buy a clothes of BOSIDENG. So, I feel so embarrassed. Finally, I say sorry to the clerk for my impolite behave.

a

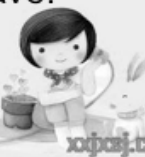

And I even thought I had never seen the beautiful down jacket before. So I found a suitable size immediately. When I worn it , my friend and I both thought it was designed for me. I decided to buy it without hesitation. After I went back to school, I found that the brand mark is SNOW FLYING! Not the BOSIDENG. I realized that maybe I was cheated by the shop. So I went to the store again and asked the clerk loudly. The store was full of the nervous atmosphere. And I waited for the clerk to give me a reas (rable) explanation

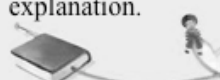

